\title{
Precautionary Savings in the Great Recession
}

\author{
ASHOKA MODY, FRANZISKA OHNSORGE, and DAMIANO SANDRI*
}

Heightened uncertainty since the onset of the Great Recession has materially increased saving rates, contributing to lower consumption and GDP growth. Consistent with a model of precautionary savings in the face of uncertainty, the paper finds for a panel of advanced economies that greater labor income uncertainty is significantly associated with higher household savings. These results are robust to controlling for other determinants of saving rates, including wealth-to-income ratios, the government fiscal balance, demographics, credit conditions, and global growth and financial stress. The estimates imply that at least two-fifths of the sharp increase in household saving rates between 2007 and 2009 can be attributed to the precautionary savings motive. [JEL E12, E32, F32, F43]

IMF Economic Review (2012) 60, 114-138. doi:10.1057/imfer.2012.5

feature of the Great Recession has been a striking increase in
uncertainty. This new environment stands in marked contrast to the
immediately preceding years of apparent tranquility, often characterized as
the Great Moderation. The transition was marked by the initially innocuous
subprime tremors in the U.S. markets in mid-2007, which were followed in

*Ashoka Mody is Deputy Director in the IMF Research Department. Franziska Ohnsorge, and Damiano Sandri are economists in the IMF European Department. The authors are grateful to Olivier Blanchard, Christopher Carroll, Thomas Harjes, Philip Lane, Jaewoo Lee, Daniel Leigh, Steve Kamin, Martin Weitzmann, and seminar participants at the Deutsche Bundesbank for comments. The paper has greatly benefited from the comments of the editor, Pierre-Olivier Gourinchas, and two anonymous referees. The views expressed herein are those of the authors and do not necessarily represent those of the IMF or IMF policy. 
late 2008 and early 2009 by an existential threat to the global financial system. Along with financial market tensions, world production and trade fell precipitously at rates exceeding that of the Great Depression (Eichengreen and O'Rourke, 2010). Not only did economic activity decline, the pace of decline was characterized by a high degree of uncertainty. Starting in late 2008, the uncertainties were reflected in repeated and sizable downward revisions of growth projections (Figure 1). Although economic recovery was widespread in 2010, new concerns - associated with financial and sovereign stress in Europe but extending to encompass global production and trade - have once again created an uncertain outlook, with a new round of downward growth revisions for 2012. Heightened uncertainty has become the new normal.

How has the elevated uncertainty influenced consumption decisions? Figure 2 shows the nearly ubiquitous decline in consumption growth between 2007 and 2009 for the sample of countries we study. The figure also shows that the decline in consumption growth was associated with a rise in household saving rates. There are good reasons to think that the rise in uncertainty and increase in saving were related. ${ }^{1}$ Examining that proposition is the purpose of this paper.

Greater uncertainty is expected to increase the incentive of households to save as they seek to protect themselves against the higher likelihood of adverse outcomes. Important contributions to the theoretical literature on precautionary savings include Leland (1968), Skinner (1988), Zeldes (1989), Caballero (1991), Deaton (1991), and Carroll (1992). We use the insights of this literature to specify an empirically useful framework to guide the econometric analysis of aggregate national household savings in a crosscountry panel setting.

The importance of precautionary saving has been documented at the individual and household levels both with reduced form and structural approaches (Carroll and Samwick, 1997; Engen and Gruber, 2001; Gourinchas and Parker, 2002; Cagetti, 2003; Giavazzi and McMahon, 2012). In contrast, the implication of uncertainty for country-level precautionary saving has received less attention. While Loayza, SchmidtHebbel, and Serven (2000) make reference to uncertainty, their empirical proxy is inflation. ${ }^{2}$ More recently, Carroll, Slacalek, and Sommer (2012) analyze the role of precautionary motives on the aggregate saving rate, but only for the United States. This paper builds on their framework to examine the determinants of saving rates for an unbalanced panel of 27 advanced

\footnotetext{
${ }^{1}$ The role of uncertainty was highlighted by Christina Romer (1990) in her analysis of the Great Depression. She found that a high level of stock market volatility in 1929 induced caution in the purchase of consumer durables and, thereby, contributed to the sharp decline in consumption.

${ }^{2}$ Several other papers have analyzed the determinants of saving rates using cross-country panel data, among which Schmidt-Hebbel, Webb, and Corsetti (1992), Edwards (1996), and Masson, Bayoumi, and Samiei (1998).
} 
Figure 1. Consensus Forecasts for 2009 Real GDP Growth

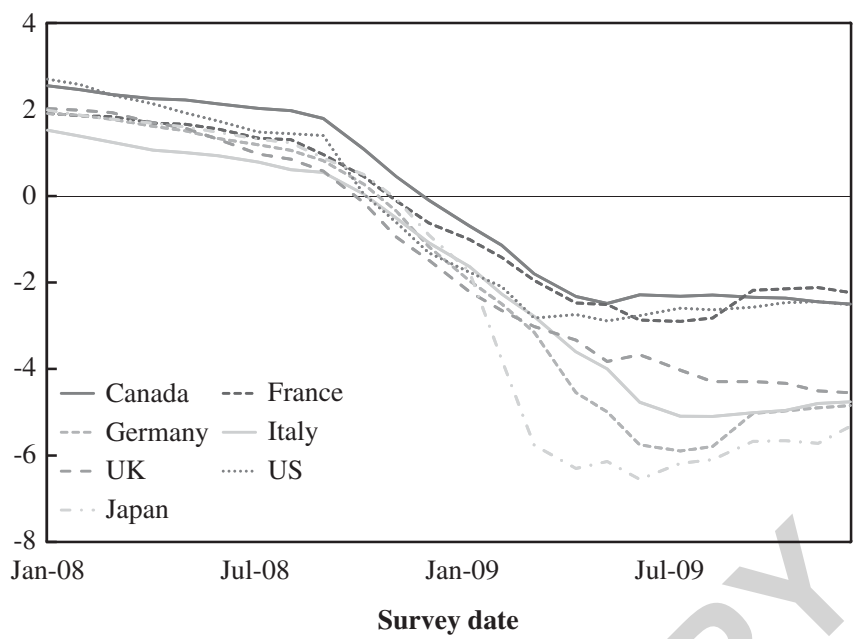

Figure 2. Change in Real Private Consumption Growth and Household Saving Rates, 2007-09



economies, with 1980 the earliest year and 2010 the latest. We then use our estimates to assess the importance of the precautionary savings motive in explaining the rise in saving rates during the Great Recession.

In the first part of this paper, we present a simple model of precautionary savings. The model is intended to capture the key themes of a broad class of models commonly used in the precautionary savings literature. An increase in labor income uncertainty stimulates saving rates 
since households accumulate a larger stock of wealth to offset larger or more frequent adverse shocks. In contrast, the response of the saving rate to changes in investment risk is subject to two counterbalancing effects: higher uncertainty stimulates precautionary savings but the risk of capital losses deters saving. The overall impact is thus ambiguous. The model also illustrates that a reduction in wealth requires a higher saving rate as households accumulate savings to regain the optimal level of precautionary wealth.

Closely following the model framework, we begin the econometric analysis by focusing on the role of labor income risk. The economy-wide unemployment rate - proxying the risk of a catastrophic income loss - is positively correlated with the saving rate even after controlling for disposable income growth and the interest rate. Saving rates are positively correlated also with our measure of GDP volatility that is likely to capture other aspects of income volatility not strictly linked to unemployment risk. Consistent with the model, investment risk — measured by the volatility of the stock marketdoes not have a significant impact on the saving rate.

These results are robust to the inclusion of various country-specific determinants that are often included in saving regressions (see Loayza, Schmidt-Hebbel, and Serven, 2000 for a comprehensive assessment of the determinants of saving rates). Among these, we find a negative correlation with both financial and housing wealth. A decline in the government fiscal balance (increase in the deficit) is associated with higher household savings, possibly capturing Ricardian effects. Saving rates are decreasing in the old dependency ratio as predicted by life-cycle theories. Finally, we find that saving rates increase when the domestic credit supply tightens. Among global variables, the expectation of higher world GDP growth is associated with lower savings rates, while financial stress in the interbank market tends to increase saving.

Based on these estimates, we find that at least two-fifths of the increase in saving rates between 2007 and 2009 can be attributed to unemployment risk and the measure of GDP volatility. However, the impact of uncertainty on saving may be larger to the extent that higher savings in response to reduced asset values also represents precautionary behavior.

\section{A Model of Precautionary Savings}

In this section we consider a simple model of precautionary savings to help clarify how uncertainty is expected to affect the saving rate. We consider an infinitely lived agent with a constant relative risk aversion utility function. This person earns a stochastic stream of labor income $Y_{t+1}$ and at each point in time decides how much to consume $C_{t}$ and how much to save $S_{t}$. The return on saving $r_{t+1}$ is also stochastic, so we can analyze the impact on the saving rate not only from variations in labor income risk, but also from changes in investment risk. Formally, the dynamic optimization problem solved by the agent can be expressed in recursive formulation as 
follows:

$$
\begin{aligned}
V\left(W_{t}\right) & =\max _{C_{t} \leqslant W_{t}}\left\{u\left(C_{t}\right)+\beta E_{t}\left[V\left(W_{t+1}\right)\right]\right\}, \\
S_{t} & =W_{t}-C_{t}, \\
W_{t+1} & =S_{t}\left(1+r_{t+1}\right)+Y_{t+1}
\end{aligned}
$$

where $\beta$ is the intertemporal discount factor and $W_{t}$ is the stock of wealth. Note that we have imposed that consumption cannot exceed current wealth so that savings cannot be negative.

To capture unemployment risk $u$, labor income $Y_{t+1}$ has the following binary distribution:

$$
Y_{t+1}=\left\{\begin{array}{ll}
Y * \lambda & \text { with probability }(1-u) \\
Y * \zeta & \text { with probability } u
\end{array},\right.
$$

where $Y$ is the deterministic permanent income level, $\zeta$ is the unemployment insurance replacement rate, and $\lambda$ is a correction factor set equal to $(1-u \zeta) /$ $(1-u)$ so that $E_{t} Y_{t+1}=Y$, irrespectively of the level of unemployment. Without such a correction, an increase in unemployment would affect the saving rate through both a reduction in expected income and an increase in the variance. By introducing $\lambda$ we are instead able to focus exclusively on the second channel. ${ }^{3}$ The return on savings $r_{t+1}$ also follows a binary distribution

$$
Y_{t+1}= \begin{cases}r+\eta & \text { with probability } 0.5 \\ r-\eta & \text { with probability } 0.5\end{cases}
$$

where $r$ is the expected rate of return and $\eta$ determines the size of the investment shock.

Regarding the calibration of the model, we use a risk aversion parameter equal to 2 , a 50 percent replacement rate $\zeta$, a 2 percent expected return $r$, and set the intertemporal discount factor $\beta$ to $0.98 .{ }^{4}$ For the distribution of labor income and investment risk, we start with a 5 percent unemployment rate $u$, and 1 percent return risk $\eta$, and will consider how the saving rate changes under alternative parameter values. We normalize the optimization problem

\footnotetext{
${ }^{3}$ Alternatively, we could assume that permanent income $Y$ is multiplied by a lognormally distributed mean-one shock $\varepsilon$. The model responses to an increase in the variance of $\varepsilon$ are qualitatively identical to an increase in unemployment $u$. We thus preferred to use our unemployment specification since the unemployment rate will be used as one of the regressors.

${ }^{4}$ More precisely, $\beta$ is set to 0.97933 in order for the model to generate an equilibrium wealth-to-income ratio of 2 . This is the average ratio of financial net worth to disposable income in our data set between 2005 and 2009.
} 
Figure 3. Higher Unemployment Risk Increases the Saving Rate
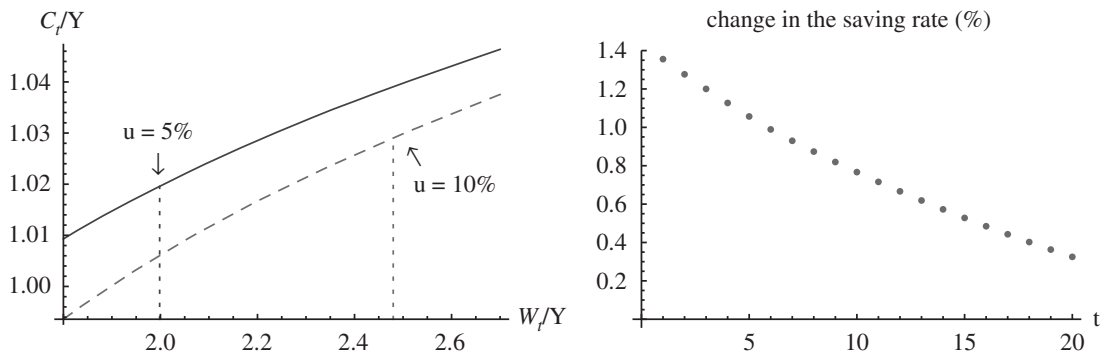

by permanent income and solve it using numerical solution methods. The model generates an equilibrium wealth-to-income ratio that the agent wants to hold to optimally insure against fluctuations in labor and investment income. Starting from such an equilibrium level, we are now going to trace the responses of the saving rate to a series of shocks.

We first consider the impact of a permanent and unexpected increase in the unemployment rate $u$ from 5 to 10 percent. Figure 3 shows on the left side the consumption functions associated with either level of unemployment and on the right side the dynamic response of the saving rate, expressed in percentage point deviations from the equilibrium with low unemployment. The solidline consumption function refers to the low unemployment state and the dotted vertical line identifies the corresponding equilibrium with a wealth-to-income ratio of 2 . The increase in unemployment shifts the consumption function down (dashed line), since the agent cuts consumption to accumulate more precautionary savings. The impulse response function on the right side shows indeed that the saving rate increases in response to higher unemployment.

Moving to the role of investment risk, we analyze the saving rate response to a permanent increase in the size of the shock $\eta$ from 1 to 3 percent. This increases the variance of the rate of return which now involves the possibility of capital losses (or negative returns). The left-side plot of Figure 4 reveals that the increase in investment risk changes the consumption function only minimally and thus has minor effects on the saving rate. If anything, under the current calibration the saving rate falls in response to higher uncertainty. This is because higher investment risk generates counterbalancing effects on saving incentives. On the one hand, higher risk increases the volatility of future consumption and thus stimulates the accumulation of precautionary savings. On the other hand, a more uncertain rate of return reduces the attractiveness of saving since it increases the risk of capital losses. ${ }^{5}$

${ }^{5}$ For an early discussion of the impact of investment risk on saving, see Sandmo (1970). The ambiguous role of investment risk for aggregate saving in general equilibrium is analyzed in Angeletos (2007). 
Figure 4. The Saving Rate Is Little Influenced by Changes in Investment Risk


Figure 5. The Saving Rate Increases after Wealth Losses
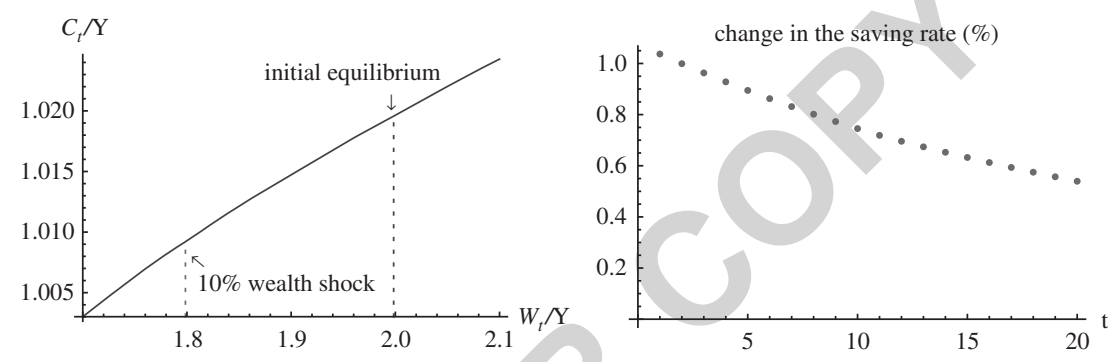

Depending on the specific calibration, either effect may prevail, but in general the impact on the saving rate is muted.

Finally, the model can be used to analyze the saving response to variations in wealth. We consider for example an exogenous 10 percent reduction in wealth that as shown on the left-side plot of Figure 5 reduces the wealth-to-income ratio from 2 to 1.8 . Following such a reduction, the agent cuts consumption and increases the saving rate in order to go back to the optimal level of precautionary assets.

Summing up, the model provides a series of implications that will be tested in the econometric analysis. An increase in unemployment risk is expected to increase the saving rate, while higher investment risk should have no clear impact on the saving rate. The saving rate should also increase in response to a reduction in wealth.

\section{Econometric Approach}

Our dependent variable is the household net saving rate as reported by the OECD. As suggested by our model, we estimate the saving rate as a function of measures of income uncertainty, expected income growth, interest rate, and wealth. With regard to income uncertainty, we employ three measures. First, we use the unemployment rate as a proxy for labor income uncertainty 
exactly as in the context of the model. ${ }^{6}$ One caveat is that an increase in the unemployment rate affects not only the second moment of the income distribution, but generates also a reduction in expected income. We control for the latter effect by including the one-period ahead real disposable income growth, as reported by the OECD. Since unemployment risk clearly does not encompass all the ways through which uncertainty can affect labor income, we also use a second broader measure of uncertainty. As described in more detail below, we consider a direct measure of the forecast uncertainty of per capita real GDP growth as estimated by a GARCH model. Finally, in order to focus on investment risk (rather than labor income uncertainty), we use a measure of the stock market volatility.

We proxy wealth as household financial net worth as a share of disposable income, lagged by one year to avoid reverse causality from household savings to wealth. We recognize that this measure excludes an important category of household assets: housing wealth. To our knowledge, data on the stock of housing wealth are not available on a comparable cross-country basis. We do, however, control in some specifications for the growth rate of house prices as a robustness check. The interest rate is measured with the real short-term deposit rate reported in the WEO database.

In sum, below we use the following regression specification:

$$
s_{t}=\alpha_{0}+\alpha_{1} U R_{t}+\alpha_{2} \Delta \ln D I_{t+1}+\alpha_{3} R_{t}+\alpha_{4} V_{t}+\alpha_{5} S M_{t}+\alpha_{6} W_{t-1}+\varepsilon_{t},
$$

where $s_{t}$ is the saving rate, $U R_{t}$ is the contemporaneous unemployment rate, $\Delta \ln D I_{t+1}$ is the log change in household real disposable income one year ahead, $R_{t}$ is the real deposit interest rate, $V_{t}$ and $S M_{t}$ are the volatility of GDP and the stock market, respectively, and $W_{t}$ is household wealth-todisposable income lagged by one year.

A few more preliminaries are necessary. The Data Appendix reports the sample periods for each of the 27 advanced economies in our data set. Since we are not persuaded of the quality of quarterly data, especially of disposable income and household wealth, we use annual data and panel data techniques. In doing so, we make the assumption that the saving rate function is the same for all countries, the differences arising entirely from the differences in the explanatory variables.

Before proceeding with the econometric analysis, the usual cautionary remarks when using macro data are needed. We follow the large consumption and saving literature and interpret our regressors as reasonable determinants of household saving rates. But concerns about endogeneity cannot be dismissed. For example, there might be some reverse causality

${ }^{6}$ For the United States, the University of Michigan's index of unemployment expectations provides an alternative measure of unemployment prospects. Carroll and Slacalek (2009) estimate a consumption growth equation using as an explanatory variable the fraction of consumers who expect the unemployment rate to decline over the next year minus the fraction who expect it to increase. 
from savings to unemployment, in so far as an exogenous increase in saving reduces aggregate demand and labor demand. This concern is, at least, somewhat less important than in earlier analyses of saving rates, since the process of globalization over the last two decades has reduced the dependence of domestic production on domestic demand and financing. Similarly, the endogeneity of the interest rate with respect to the domestic saving supply has weakened. Caution is also advisable in the interpretation of wealth effects, since higher saving rates naturally lead to an increase in wealth, at least to the extent they are not offset by a reduction in asset prices. To limit this problem, we lag the wealth-to-income ratio by one year. Finally, there is always the possibility that some omitted variable might be causing a spurious correlation between saving rates and the regressors. To control for this, we will add to the regression country fixed effects as well as variables that capture the world economic cycle and thus absorb common variation across countries.

\section{Savings and Uncertainty}

Table 1 builds the foundation of our eventual baseline regression. We begin with a country fixed-effect regression of the saving rate over the unemployment rate in column (1). Consistent with the model, the regression coefficient is positive and highly statistically significant. A 1 percent increase in unemployment is associated with a half percent increase in the saving rate. As previously discussed, higher unemployment may lead to higher saving rates not only by increasing labor income risk, but also by reducing expected income. To control for the latter effect we add in column (2) real disposable income growth between the current and next year. As expected, a reduction in income growth increases the saving rate and mildly reduces the size of the coefficient on unemployment. Finally, in column (3) we include among the regressors also the deposit rate, which is positively correlated with the saving rate consistent with an intertemporal substitution mechanism. The results hold also when using a random effect specification as shown in columns (4) and (5).

Next, we consider the role of other measures of uncertainty. We first add a broad measure of income uncertainty $V_{t}$. This is defined as the instantaneous time-varying standard deviation of per capita real GDP growth $V_{t}$, as estimated by a first-order GARCH model using data since the 1960s, or beginning with the earliest data available. Many of the smaller advanced economies have on average experienced greater GDP volatility. However, some large economies also had periods of heightened volatility: Japan during its housing bust in the early 1990s, France during the political turmoil of the late 1960s, or the United Kingdom during the 1970s and 1980s oil price shocks and the 1990 s exchange rate mechanism crisis. Volatility spikes around the oil price shocks also prevailed in the United States and Italy but were of a smaller magnitude. German data only begin with reunification in the early 1990s. From then until recently, fewer international 
Table 1. Saving Rates and Unemployment Risk

\begin{tabular}{|c|c|c|c|c|c|}
\hline \multirow{3}{*}{$\frac{\text { Variables }}{\text { Unemployment rate }}$} & (1) & (2) & (3) & (4) & (5) \\
\hline & \multicolumn{3}{|c|}{ Country fixed effects } & \multicolumn{2}{|c|}{ Random effects } \\
\hline & $\begin{array}{l}0.55^{* * *} \\
{[5.15]}\end{array}$ & $\begin{array}{l}0.49 * * * \\
{[4.43]}\end{array}$ & $\begin{array}{l}0.34 * * * \\
{[3.23]}\end{array}$ & $\begin{array}{l}0.48 * * * \\
{[4.65]}\end{array}$ & $\begin{array}{l}0.30^{* * * *} \\
{[2.94]}\end{array}$ \\
\hline $\begin{array}{l}\text { Lead of disposable } \\
\text { income growth }\end{array}$ & & $\begin{array}{l}-0.18 * * \\
{[-2.46]}\end{array}$ & $\begin{array}{l}-0.19 * * * \\
{[-2.62]}\end{array}$ & & $\begin{array}{l}-0.20^{* * *} \\
{[-2.75]}\end{array}$ \\
\hline $\begin{array}{l}\text { Real short-term deposit } \\
\text { rate }\end{array}$ & & & $\begin{array}{l}0.74 * * * \\
{[9.36]}\end{array}$ & & $\begin{array}{l}0.75^{* * *} \\
{[9.53]}\end{array}$ \\
\hline Constant & $\begin{array}{l}2.68^{* * *} \\
{[3.47]}\end{array}$ & $\begin{array}{l}3.60^{* * *} \\
{[4.38]}\end{array}$ & $\begin{array}{l}3.40^{* * *} \\
{[4.44]}\end{array}$ & $\begin{array}{r}2.38^{*} \\
{[1.89]}\end{array}$ & $\begin{array}{l}3.12^{* *} \\
{[2.50]}\end{array}$ \\
\hline Observations & 473 & 454 & 434 & 473 & 434 \\
\hline Within $R$-squared & 0.06 & 0.06 & 0.23 & 0.06 & 0.23 \\
\hline Number of countries & 27 & 27 & 26 & 27 & 26 \\
\hline
\end{tabular}

$t$-statistics in brackets.

$* * * p<0.01, * * p<0.05, * p<0.1$.

Coefficients for country and year dummies not reported.

shocks have buffeted advanced economies, hence the range of estimated volatilities is narrower for Germany. Following a period of historically low volatility in most advanced economies during the early and mid-2000s, volatility rose again during the global financial crisis of 2008/09 (Figure 6). Exceptions were commodity producers and financial centers; Ireland and Spain, where volatility peaked in 2008 as real estate markets weakened sharply; and Portugal, where the crisis intensified mostly in 2010 as spillovers from financial turmoil in the eurozone gathered strength.

Columns (2) and (4) in Table 2 show the results for our measure of GDP volatility $V^{7}$ The measure is highly significant with the expected sign: an increase in income uncertainty by 1 percent is associated with a higher household saving rate by about 1 percentage point. This variable proves robust through the many specifications that we explore below. The coefficient on the unemployment rate remains highly significant and broadly unchanged in magnitude. Together, then, the salience of the unemployment rate and GDP volatility constitutes in our view evidence in favor of the role of uncertainty and precautionary behavior in our sample of countries. Controlling for GDP volatility also strengthens the coefficient on expected income growth in both magnitude and statistical significance.

With financial markets unusually volatile since 2008, a question of particular interest is the empirical importance of financial market volatility on savings behavior. The relationship between stock market volatility and real economic activity has recently been highlighted by Bloom (2009) and

${ }^{7}$ To facilitate comparison with the previous regression results, column (1) of Table 2 reports the estimates in column (3) of Table 1. 
Figure 6. Change in Estimated Standard Deviation of Real Per Capita GDP Growth, 2008-09

(In percent)

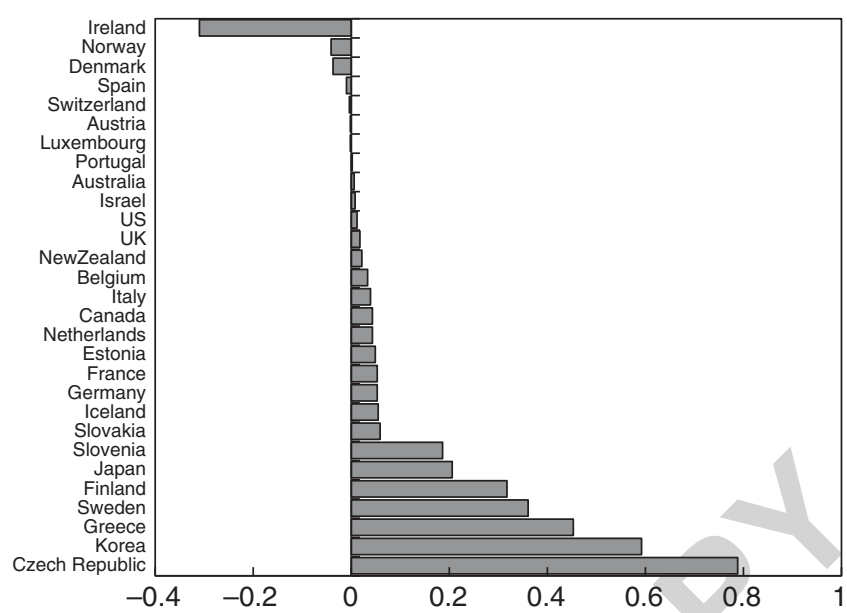

Table 2. Other Measures of Volatility

\begin{tabular}{|c|c|c|c|c|c|c|c|}
\hline \multirow[b]{2}{*}{ Variables } & (1) & (2) & (3) & (4) & (5) & (6) & (7) \\
\hline & \multicolumn{4}{|c|}{ Country fixed effects } & \multicolumn{3}{|c|}{ Random effects } \\
\hline $\begin{array}{l}\text { Unemployment } \\
\text { rate }\end{array}$ & $\begin{array}{l}0.34^{* * *} \\
{[3.23]}\end{array}$ & $\begin{array}{l}0.31 * * * \\
{[3.17]}\end{array}$ & $\begin{array}{l}0.34 * * * \\
{[3.02]}\end{array}$ & $\begin{array}{l}0.30 * * * \\
{[2.83]}\end{array}$ & $\begin{array}{l}0.29 * * * \\
{[3.03]}\end{array}$ & $\begin{array}{l}0.31 * * * \\
{[2.83]}\end{array}$ & $\begin{array}{l}0.30^{* * *} \\
{[2.84]}\end{array}$ \\
\hline $\begin{array}{l}\text { Lead of disposable } \\
\text { income growth }\end{array}$ & $\begin{array}{l}-0.19^{* * *} \\
{[-2.62]}\end{array}$ & $-0.31^{* * *}$ & $\begin{array}{l}-0.22^{* * * *} \\
{[-2.67]}\end{array}$ & $\begin{array}{l}-0.32^{* * *} \\
{[-4.18]}\end{array}$ & $\begin{array}{l}-0.34 * * * \\
{[-4.54]}\end{array}$ & $\begin{array}{l}-0.23^{* * *} \\
{[-2.82]}\end{array}$ & $\begin{array}{l}-0.34 * * * \\
{[-4.40]}\end{array}$ \\
\hline $\begin{array}{l}\text { Real short-term } \\
\text { deposit rate }\end{array}$ & $\begin{array}{l}0.74 * * * \\
{[9.36]}\end{array}$ & $\begin{array}{l}0.77 * * * \\
{[9.76]}\end{array}$ & $\begin{array}{l}0.83^{* * * *} \\
{[9.46]}\end{array}$ & $\begin{array}{l}0.81 * * * \\
{[9.93]}\end{array}$ & $\begin{array}{l}0.77 * * * \\
{[9.81]}\end{array}$ & $\begin{array}{l}0.83 * * * \\
{[9.53]}\end{array}$ & $\begin{array}{l}0.81^{* * * *} \\
{[9.88]}\end{array}$ \\
\hline GDP volatility & & $\begin{array}{l}0.96 * * * \\
{[4.67]}\end{array}$ & & $\begin{array}{l}1.05^{* * * *} \\
{[4.83]}\end{array}$ & $\begin{array}{l}0.77 * * * \\
{[3.91]}\end{array}$ & & $\begin{array}{l}0.91 * * * \\
{[4.28]}\end{array}$ \\
\hline $\begin{array}{l}\text { Stock market } \\
\text { volatility }\end{array}$ & & & $\begin{array}{c}0.23 \\
{[0.71]}\end{array}$ & $\begin{array}{l}-0.02 \\
{[-0.07]}\end{array}$ & & $\begin{array}{c}0.21 \\
{[0.64]}\end{array}$ & {$\left[\begin{array}{c}0 \\
-0.01]\end{array}\right]$} \\
\hline Constant & $\begin{array}{l}3.40^{* * *} \\
{[4.44]}\end{array}$ & $\begin{array}{c}1.03 \\
{[1.21]}\end{array}$ & $\begin{array}{l}2.92^{* * *} \\
{[3.04]}\end{array}$ & $\begin{array}{c}1.04 \\
{[1.10]}\end{array}$ & $\begin{array}{c}1.18 \\
{[0.92]}\end{array}$ & $\begin{array}{l}2.94^{* *} \\
{[2.06]}\end{array}$ & $\begin{array}{l}1.17 \\
{[0.84]}\end{array}$ \\
\hline Observations & 434 & 419 & 407 & 402 & 419 & 407 & 402 \\
\hline Within $R$-squared & 0.23 & 0.32 & 0.26 & 0.34 & 0.32 & 0.26 & 0.34 \\
\hline $\begin{array}{l}\text { Number of } \\
\text { countries }\end{array}$ & 26 & 26 & 24 & 24 & 26 & 24 & 24 \\
\hline
\end{tabular}

$t$-statistics in brackets.

$* * * p<0.01,{ }^{* *} p<0.05, * p<0.1$.

Coefficients for country dummies not reported.

Bloom, et al. (2011), who however focused on investment and output. Regarding instead the impact of uncertainty in the rate of return on saving behavior, our model predicts that it should be muted. While higher 
uncertainty stimulates precautionary saving, the risk of negative returns acts as a deterrent. To test this prediction, we add in columns (3) and (4) of Table 2 the volatility of the domestic stock market, measured as the standard deviation of daily changes in the stock market index over a year. Consistent with our model, market volatility has no clear influence on the saving rate in our sample. We tried a variety of different specifications, but stock market volatility never rose to significance. ${ }^{8}$

\section{Other Determinants of Savings}

Another variable that according to our model should influence the saving rate is the wealth-to-income ratio. In a model of precautionary savings, consumers want to hold a certain optimal level of wealth to buffer possible income shocks. The saving rate should thus increase in response to a negative wealth shock, since consumers try to re-accumulate assets. Table 3 reports the results when the lagged financial net worth to income ratio is added to the regressors. ${ }^{9}$ Consistent with the model, households' net financial wealth is negatively correlated with household saving rates.

Of course, financial wealth is only a fraction of total household wealth. Ideally, we would like to include an indicator of housing wealth as well. Comparable cross-country data on the stock of housing wealth are, to our knowledge, not available. However, the Bank for International Settlements has compiled a large panel data set on housing prices from which we extract as comparable a set of housing prices as possible. For lack of alternatives, we assume that the housing stock is constant over time-admittedly, a strong assumption - and that only housing prices change over time. Just as we did with household net financial wealth, we scale our measure of "housing wealth" by household income and include its change into the regression in column (3) of Table $3 .^{10}$ This imperfect measure of the increase in housing wealth is significantly negatively correlated with household saving rates. In the rest of the paper, in order to preserve a larger sample, we exclude our housing variable and interpret the financial wealth as capturing some of the effect of housing wealth.

There are several other possible determinants of saving rates that we have not formally incorporated in the model, but are commonly used in estimations of saving rates. According to the Ricardian equivalence proposition, households offset government dissaving in expectation of higher taxes. In column (2) of Table 4, we test for the Ricardian equivalence hypothesis by

\footnotetext{
${ }^{8}$ It is possible that stock market volatility reduces investment and increases unemployment. The impact of stock market volatility may thus be subsumed in other explanatory variables that we use.

${ }^{9}$ For reference as a baseline, the column (1) of Table 3 includes the results of column (2) in Table 2.

${ }^{10} \mathrm{We}$ could have alternatively included the house price-to-income ratio rather than its change. However, that measure would be difficult to interpret since it is a ratio of normalized indices. Furthermore, in our sample, saving rates appear to be correlated with the change in the index rather than the level of the index.
} 
Table 3. Wealth Effects

\begin{tabular}{|c|c|c|c|c|c|}
\hline \multirow{3}{*}{$\frac{\text { Variables }}{\text { Unemployment rate }}$} & (1) & (2) & (3) & (4) & (5) \\
\hline & \multicolumn{3}{|c|}{ Country fixed effects } & \multicolumn{2}{|c|}{ Random effects } \\
\hline & $\begin{array}{l}0.31 * * * \\
{[3.17]}\end{array}$ & $\begin{array}{l}0.35^{* * *} \\
{[3.78]}\end{array}$ & $\begin{array}{l}0.31 * * * \\
{[3.31]}\end{array}$ & $\begin{array}{l}0.37 * * * \\
{[4.08]}\end{array}$ & $\begin{array}{l}0.33^{* * *} \\
{[3.49]}\end{array}$ \\
\hline $\begin{array}{l}\text { Lead of disposable } \\
\text { income growth }\end{array}$ & $\begin{array}{l}-0.31 * * * \\
{[-4.21]}\end{array}$ & $\begin{array}{l}-0.29 * * * \\
{[-4.34]}\end{array}$ & $\begin{array}{l}-0.28 * * * \\
{[-4.24]}\end{array}$ & $\begin{array}{l}-0.33^{* * *} \\
{[-4.90]}\end{array}$ & $\begin{array}{l}-0.29 * * * \\
{[-4.26]}\end{array}$ \\
\hline Real short-term deposit rate & $\begin{array}{l}0.77 * * * \\
{[9.76]}\end{array}$ & $\begin{array}{l}0.54^{* * * *} \\
{[6.21]}\end{array}$ & $\begin{array}{l}0.71 * * * \\
{[8.56]}\end{array}$ & $\begin{array}{l}0.58^{* * *} \\
{[6.47]}\end{array}$ & $\begin{array}{l}0.68^{* * *} \\
{[8.18]}\end{array}$ \\
\hline GDP volatility & $\begin{array}{l}0.96^{* * *} \\
{[4.67]}\end{array}$ & $\begin{array}{l}0.69^{* * *} \\
{[3.30]}\end{array}$ & $\begin{array}{l}0.81 * * * \\
{[4.70]}\end{array}$ & $\begin{array}{l}0.49^{* *} \\
{[2.43]}\end{array}$ & $\begin{array}{l}0.68^{* * *} \\
{[4.00]}\end{array}$ \\
\hline $\begin{array}{l}\text { Lagged financial net worth } \\
\text { (scaled by disposable income) }\end{array}$ & & $\begin{array}{l}-2.17^{* * *} \\
{[-5.09]}\end{array}$ & & $\begin{array}{l}-1.53^{* * *} \\
{[-3.78]}\end{array}$ & \\
\hline $\begin{array}{l}\text { Change in house prices } \\
\text { (scaled by disposable income) }\end{array}$ & & & $\begin{array}{l}-21.43 * * * \\
{[-7.69]}\end{array}$ & & $\begin{array}{l}-21.81 * * * \\
{[-7.70]}\end{array}$ \\
\hline Constant & $\begin{array}{c}1.03 \\
{[1.21]}\end{array}$ & $\begin{array}{l}6.47^{* * *} \\
{[4.38]}\end{array}$ & $\begin{array}{c}0.96 \\
{[1.32]}\end{array}$ & $\begin{array}{l}5.00^{* * *} \\
{[2.93]}\end{array}$ & $\begin{array}{c}1.22 \\
{[1.00]}\end{array}$ \\
\hline Observations & 419 & 326 & 268 & 326 & 268 \\
\hline Within $R$-squared & 0.32 & 0.40 & 0.53 & 0.39 & 0.53 \\
\hline Number of countries & 26 & 25 & 19 & 25 & 19 \\
\hline
\end{tabular}

$t$-statistics in brackets.

$* * * p<0.01, * * p<0.05, * p<0.1$.

Coefficients for country dummies not reported.

controlling for the general government structural balance in percent of potential GDP. ${ }^{11}$ The structural fiscal balance is significantly negatively correlated with the household saving rate: a widening of the government deficit by 1 percentage point of GDP raises the household saving rate by around 0.2 percentage points.

Another factor that is commonly found to influence the household saving rate is the demographic structure. To account for that, we introduce the old and young dependency ratios, defined respectively as the percentage of people aged 65 and above, and children between 0 and 14, relative to the working age population. An increase in the old dependency ratio reduces saving rates (column (3) of Table 4). This is consistent with Modigliani's life-cycle theory, according to which the elderly have lower saving rates since retirement income is lower than permanent income and because they can support consumption by running down their retirement savings. The role of the young dependency ratio is theoretically more ambiguous: the presence of children may require households to face higher expenses that would reduce the saving rate, but could also stimulate extra savings to pay for college

${ }^{11}$ Column (1) is again provided as reference for the reader's convenience; it is the same as column (2) in Table 3. 
Table 4. Other Common Control Variables

\begin{tabular}{|c|c|c|c|c|c|c|c|c|c|}
\hline \multirow{3}{*}{$\frac{\text { Variables }}{\text { Unemployment rate }}$} & (1) & (2) & (3) & (4) & (5) & (6) & (7) & (8) & (9) \\
\hline & \multicolumn{5}{|c|}{ Country fixed effects } & \multicolumn{4}{|c|}{ Random effects } \\
\hline & $\begin{array}{l}0.35^{* * *} \\
{[3.78]}\end{array}$ & $\begin{array}{l}0.28^{* * * *} \\
{[2.84]}\end{array}$ & $\begin{array}{l}0.29 * * * \\
{[3.41]}\end{array}$ & $\begin{array}{l}0.24 * * * \\
{[2.71]}\end{array}$ & $\begin{array}{l}0.24 * * * \\
{[2.70]}\end{array}$ & $\begin{array}{l}0.28^{* * *} \\
{[2.84]}\end{array}$ & $\begin{array}{l}0.33^{* * *} \\
{[3.87]}\end{array}$ & $\begin{array}{l}0.29 * * * \\
{[3.31]}\end{array}$ & $\begin{array}{l}0.27 * * * \\
{[3.05]}\end{array}$ \\
\hline Lead of disposable income growth & $\begin{array}{l}-0.29 * * * \\
{[-4.34]}\end{array}$ & $\begin{array}{l}-0.25^{* * *} \\
{[-3.35]}\end{array}$ & $-0.33^{* * *}$ & $\begin{array}{l}-0.31 * * * \\
{[-4.96]}\end{array}$ & $\begin{array}{l}-0.30 * * * \\
{[-4.42]}\end{array}$ & $\begin{array}{l}-0.27 * * * \\
{[-3.69]}\end{array}$ & $\begin{array}{l}-0.37 * * * \\
{[-5.73]}\end{array}$ & $\begin{array}{l}-0.35^{* * *} \\
{[-5.41]}\end{array}$ & $\begin{array}{l}-0.34 * * * \\
{[-4.93]}\end{array}$ \\
\hline Real short-term deposit rate & $\begin{array}{l}0.54^{* * *} \\
{[6.21]}\end{array}$ & $\begin{array}{l}0.50^{* * *} \\
{[5.16]}\end{array}$ & $\begin{array}{l}0.41^{* * *} \\
{[4.92]}\end{array}$ & $\begin{array}{l}0.37 * * * \\
{[4.31]}\end{array}$ & $\begin{array}{l}0.40^{* * *} \\
{[4.57]}\end{array}$ & $\begin{array}{l}0.52^{* * *} \\
{[5.30]}\end{array}$ & $\begin{array}{l}0.45^{* * *} \\
{[5.27]}\end{array}$ & $\begin{array}{l}0.41^{* * * *} \\
{[4.66]}\end{array}$ & $\begin{array}{l}0.45^{* * *} \\
{[5.01]}\end{array}$ \\
\hline GDP volatility & $\begin{array}{l}0.69 * * * \\
{[3.30]}\end{array}$ & $\begin{array}{l}0.65 * * * \\
{[2.95]}\end{array}$ & $\begin{array}{l}0.70 * * * \\
{[3.60]}\end{array}$ & $\begin{array}{l}0.76^{* * * *} \\
{[3.89]}\end{array}$ & $\begin{array}{l}0.76^{* * *} \\
{[3.84]}\end{array}$ & $\begin{array}{l}0.49^{* *} \\
{[2.23]}\end{array}$ & $\begin{array}{l}0.47^{* *} \\
{[2.44]}\end{array}$ & $\begin{array}{l}0.52^{* * *} \\
{[2.70]}\end{array}$ & $\begin{array}{l}0.60^{* * *} \\
{[3.02]}\end{array}$ \\
\hline $\begin{array}{l}\text { Lagged financial net worth } \\
\text { (scaled by disposable income) }\end{array}$ & $\begin{array}{l}-2.17 * * * \\
{[-5.09]}\end{array}$ & $-1.54 * * *$ & $-1.25^{* * *}$ & $-1.29^{* * *}$ & $\begin{array}{l}-2.15^{* * * *} \\
{[-5.33]}\end{array}$ & $-0.88^{*}$ & $\begin{array}{l}-0.84^{* *} \\
{[-2.08]}\end{array}$ & $-0.91^{* *}$ & $\begin{array}{l}-1.51^{* * *} \\
{[-3.86]}\end{array}$ \\
\hline Structural balance ( $\%$ of potential GDP) & & $\begin{array}{l}-0.21^{* *} \\
{[-2.25]}\end{array}$ & & & & $\begin{array}{l}-0.25^{* * * *} \\
{[-2.81]}\end{array}$ & & & \\
\hline Old age dependency ratio $(\%)$ & & & $\begin{array}{l}-0.75^{* * *} \\
{[-6.79]}\end{array}$ & $\begin{array}{l}-0.63 * * * \\
{[-5.26]}\end{array}$ & & & $\begin{array}{l}-0.63^{* * *} \\
{[-5.99]}\end{array}$ & $\begin{array}{l}-0.54 * * * \\
{[-4.65]}\end{array}$ & \\
\hline Young dependency ratio $(\%)$ & & & & $\begin{array}{l}0.27^{* *} \\
{[2.34]}\end{array}$ & & & & $\begin{array}{l}0.23^{* *} \\
{[2.01]}\end{array}$ & \\
\hline Private sector credit ( $\%$ of GDP) & & & & & $\begin{array}{l}-0.02 * * * \\
{[-5.78]}\end{array}$ & & & & $\begin{array}{l}-0.02 * * * \\
{[-5.18]}\end{array}$ \\
\hline Constant & $\begin{array}{l}6.47^{* * * *} \\
{[4.38]}\end{array}$ & $\begin{array}{l}5.06^{* * *} \\
{[3.07]}\end{array}$ & $\begin{array}{l}21.70 * * * \\
{[8.25]}\end{array}$ & $\begin{array}{l}12.30^{* * *} \\
{[2.57]}\end{array}$ & $\begin{array}{l}10.28 * * * \\
{[6.72]}\end{array}$ & $\begin{array}{l}3.72 * * \\
{[2.02]}\end{array}$ & $\begin{array}{l}18.18^{* * * *} \\
{[6.64]}\end{array}$ & $\begin{array}{l}10.61 * * \\
{[2.25]}\end{array}$ & $\begin{array}{l}8.31^{* * *} \\
{[4.68]}\end{array}$ \\
\hline Observations & 326 & 304 & 326 & 326 & 314 & 304 & 326 & 326 & 314 \\
\hline Within $R$-squared & 0.40 & 0.37 & 0.48 & 0.49 & 0.47 & 0.36 & 0.47 & 0.48 & 0.46 \\
\hline Number of countries & 25 & 24 & 25 & 25 & 24 & 24 & 25 & 25 & 24 \\
\hline
\end{tabular}

$t$-statistics in brackets.

${ }^{* * *} p<0.01,{ }^{* *} p<0.05, * p<0.1$

Coefficients for country dummies not reported. 
education or help children buy their first house. The latter mechanism seems to prevail in our data set, as the coefficient on the young dependency ratio is positive.

Finally, we explore the importance of credit conditions for household savings. An increase in credit supply is expected to reduce saving rates, since households can more easily borrow to offset negative income shocks and can thus reduce the holdings of precautionary savings. The challenge to measure such effects is the lack of comparable cross-country measures of credit supply. For the United States, the survey of senior loan officers is commonly used as a measure of credit conditions, but similar surveys are unfortunately not generally available in other countries. ${ }^{12}$ We therefore use the domestic credit to the private sector as a percent of GDP, even though it is an imperfect measure since it also depends on credit demand. The results in columns (5) and (9) show a statistically significant and negative correlation with the saving rate, suggesting therefore that a tightening of credit conditions is associated with higher saving rates.

The regression results in Table 4 for the government balance, demographics, and credit conditions are therefore fully consistent with the implications of standard saving theories. But importantly, the introduction of these additional controls does not alter significantly the role of our measures of uncertainty which remain quite robust. We take column (2) with the structural fiscal balance as our baseline regression to assess the quantitative importance of the rise in saving rates during the Great Recession.

Our results are broadly robust to choosing subsamples, or dropping each country or each year at a time (Table 5). ${ }^{13}$ The significance of some regressors weakens instead if using three-year averages. This is not surprising since averaging smoothes out within-country variability over time which is necessary to identify the coefficient estimates in our country fixed effects regression.

\section{Global Factors}

Finally, we explore to what extent household savings are driven by global events. It is possible, for example, that households expect global shocks to be transmitted into their economic situation and, hence, respond to these over and above the reaction warranted by country developments. We consider three possibilities that encompass the current and prospective global outlook: the concurrent real growth of world GDP, the ratio of copper-to-gold price as a predictor of future growth, and the TED spread to capture financial conditions. Our forward-looking measure of growth - the ratio of copperto-gold price requires some explanation. Copper is widely used as an

\footnotetext{
${ }^{12}$ See Carroll, Slacalek, and Sommer (2012) for a recent analysis of the U.S. saving rate using the senior loan officer survey.

${ }^{13}$ To facilitate the comparison, column (1) of Table 5 repeats the results in column (2) of Table 4. All regressions in Table 5 include country fixed effects.
} 
Table 5. Robustness Checks

\begin{tabular}{|c|c|c|c|c|c|c|c|c|c|c|c|c|}
\hline & (1) & (2) & (3) & (4) & $(5)$ & (6) & (7) & (8) & (9) & (10) & (11) & (12) \\
\hline Variables & $\begin{array}{l}\text { All countries } \\
\text { and years }\end{array}$ & G7 & Non-G7 & $\begin{array}{l}\text { Excluding } \\
\text { U.S. }\end{array}$ & $\begin{array}{l}\text { Excluding } \\
\text { France }\end{array}$ & $\begin{array}{l}\text { Excluding } \\
\text { Germany }\end{array}$ & $\begin{array}{l}\text { Excluding } \\
\text { Italy }\end{array}$ & $\begin{array}{l}\text { Excluding } \\
\text { Japan }\end{array}$ & $\begin{array}{c}\text { Excluding } \\
1998\end{array}$ & $\begin{array}{c}\text { Excluding } \\
2001\end{array}$ & $\begin{array}{l}\text { Excluding } \\
2009\end{array}$ & $\begin{array}{c}\text { 3-year } \\
\text { averages }\end{array}$ \\
\hline Unemployment rate & $\begin{array}{l}0.28 * * * \\
{[2.84]}\end{array}$ & $\begin{array}{l}0.56^{* * * *} \\
{[2.96]}\end{array}$ & $\begin{array}{l}0.30 * * * \\
{[2.71]}\end{array}$ & $\begin{array}{l}0.28 * * * \\
{[2.79]}\end{array}$ & $\begin{array}{l}0.30 * * * \\
{[2.92]}\end{array}$ & $\begin{array}{l}0.27 * * * \\
{[2.62]}\end{array}$ & $\begin{array}{l}0.25^{* *} \\
{[2.39]}\end{array}$ & $\begin{array}{l}0.32 * * * \\
{[3.22]}\end{array}$ & $\begin{array}{l}0.32 * * * \\
{[3.19]}\end{array}$ & $\begin{array}{l}0.28 * * * \\
{[2.70]}\end{array}$ & $\begin{array}{l}0.26^{* *} \\
{[2.52]}\end{array}$ & $\begin{array}{c}0.37 * \\
{[1.70]}\end{array}$ \\
\hline $\begin{array}{l}\text { Lead of disposable income } \\
\text { growth }\end{array}$ & $\begin{array}{l}-0.25^{* * *} \\
{[-3.35]}\end{array}$ & $\begin{array}{l}-0.43^{* * *} \\
{[-2.69]}\end{array}$ & $\begin{array}{l}-0.22 * * * \\
{[-2.90]}\end{array}$ & $\begin{array}{l}-0.24 * * * \\
{[-3.15]}\end{array}$ & $\begin{array}{l}-0.25^{* * *} \\
{[-3.32]}\end{array}$ & $\begin{array}{l}-0.24 * * * \\
{[-3.17]}\end{array}$ & $\begin{array}{l}-0.25^{* * *} \\
{[-3.30]}\end{array}$ & $\begin{array}{l}-0.23^{* * *} \\
{[-3.21]}\end{array}$ & $\begin{array}{l}-0.27 * * * \\
{[-3.62]}\end{array}$ & $\begin{array}{l}-0.22 * * * \\
{[-2.92]}\end{array}$ & $\begin{array}{l}-0.23^{* * *} \\
{[-3.14]}\end{array}$ & $\begin{array}{c}-0.21 \\
{[-1.23]}\end{array}$ \\
\hline Real short-term deposit rate & $\begin{array}{l}0.50^{* * *} \\
{[5.16]}\end{array}$ & $\begin{array}{l}0.71^{* * *} \\
{[4.82]}\end{array}$ & $\begin{array}{l}0.27 * * \\
{[2.41]}\end{array}$ & $\begin{array}{l}0.51 * * * \\
{[5.13]}\end{array}$ & $\begin{array}{l}0.51^{* * *} \\
{[5.12]}\end{array}$ & $\begin{array}{l}0.51^{* * *} \\
{[5.13]}\end{array}$ & $\begin{array}{l}0.49 * * * \\
{[5.04]}\end{array}$ & $\begin{array}{l}0.52^{* * *} \\
{[5.48]}\end{array}$ & $\begin{array}{l}0.52^{* * *} \\
{[5.26]}\end{array}$ & $\begin{array}{l}0.50^{* * *} \\
{[4.95]}\end{array}$ & $\begin{array}{l}0.46^{* * *} \\
{[4.61]}\end{array}$ & $\begin{array}{l}1.13^{* * *} \\
{[4.24]}\end{array}$ \\
\hline GDP volatility & $\begin{array}{l}0.65^{* * *} \\
{[2.95]}\end{array}$ & $\begin{array}{c}0.73 \\
{[1.14]}\end{array}$ & $\begin{array}{l}0.69^{* * * *} \\
{[3.19]}\end{array}$ & $\begin{array}{l}0.65^{* * * *} \\
{[2.90]}\end{array}$ & $\begin{array}{l}0.65^{* * *} \\
{[2.87]}\end{array}$ & $\begin{array}{l}0.67^{* * *} \\
{[2.91]}\end{array}$ & $\begin{array}{l}0.69^{* * *} \\
{[3.11]}\end{array}$ & $\begin{array}{l}0.62 * * * \\
{[2.84]}\end{array}$ & $\begin{array}{l}0.69^{* * * *} \\
{[3.09]}\end{array}$ & $\begin{array}{l}0.66^{* * *} \\
{[2.80]}\end{array}$ & $\begin{array}{l}0.73^{* *} \\
{[2.40]}\end{array}$ & $\begin{array}{r}0.92 * \\
{[1.72]}\end{array}$ \\
\hline $\begin{array}{l}\text { Lagged financial net worth } \\
\text { (scaled by disposable income) }\end{array}$ & $\begin{array}{l}-1.54 * * * \\
{[-2.94]}\end{array}$ & $\begin{array}{l}-3.71^{* * *} \\
{[-4.30]}\end{array}$ & $\begin{array}{c}0.94 \\
{[1.46]}\end{array}$ & $\begin{array}{l}-1.60 * * * \\
{[-2.98]}\end{array}$ & $\begin{array}{l}-1.58^{* * *} \\
{[-2.94]}\end{array}$ & $\begin{array}{l}-1.69^{* * *} \\
{[-3.14]}\end{array}$ & $\begin{array}{l}-1.51^{* * *} \\
{[-2.82]}\end{array}$ & $\begin{array}{l}-1.00^{*} \\
{[-1.88]}\end{array}$ & $\begin{array}{l}-1.58^{* * *} \\
{[-2.96]}\end{array}$ & $\begin{array}{l}-1.96^{* * *} \\
{[-3.51]}\end{array}$ & $\begin{array}{l}-1.62 * * * \\
{[-3.04]}\end{array}$ & $\begin{array}{r}1.81^{*} \\
{[1.79]}\end{array}$ \\
\hline $\begin{array}{l}\text { Structural balance (\% of } \\
\text { potential GDP) }\end{array}$ & $\begin{array}{l}-0.21^{* *} \\
{[-2.25]}\end{array}$ & $\begin{array}{c}0.04 \\
{[0.27]}\end{array}$ & $\begin{array}{l}-0.20^{*} \\
{[-1.88]}\end{array}$ & $\begin{array}{l}-0.21 * * \\
{[-2.18]}\end{array}$ & $\begin{array}{l}-0.19^{* *} \\
{[-1.99]}\end{array}$ & $\begin{array}{l}-0.20^{* *} \\
{[-2.15]}\end{array}$ & $\begin{array}{l}-0.21 * * \\
{[-2.13]}\end{array}$ & $\begin{array}{l}-0.25 * * * \\
{[-2.72]}\end{array}$ & $\begin{array}{l}-0.18^{*} \\
{[-1.90]}\end{array}$ & $\begin{array}{l}-0.19 * * \\
{[-1.99]}\end{array}$ & $\begin{array}{l}-0.26^{* * *} \\
{[-2.79]}\end{array}$ & $\begin{array}{l}-0.54 * * * \\
{[-3.24]}\end{array}$ \\
\hline Constant & $\begin{array}{l}5.06^{* * *} \\
{[3.07]}\end{array}$ & $\begin{array}{l}11.35^{* * * *} \\
{[3.25]}\end{array}$ & $\begin{array}{l}-0.81 \\
{[-0.46]}\end{array}$ & $\begin{array}{l}5.16^{* * * *} \\
{[3.09]}\end{array}$ & $\begin{array}{l}4.80^{* * *} \\
{[2.84]}\end{array}$ & $\begin{array}{l}5.29 * * * \\
{[3.11]}\end{array}$ & $\begin{array}{l}4.88^{* * *} \\
{[2.93]}\end{array}$ & $\begin{array}{c}3.54 * * \\
{[2.14]}\end{array}$ & $\begin{array}{l}4.85^{* * *} \\
{[2.91]}\end{array}$ & $\begin{array}{l}5.89^{* * *} \\
{[3.41]}\end{array}$ & $\begin{array}{l}5.14 * * * \\
{[2.93]}\end{array}$ & $\begin{array}{c}-5.12 \\
{[-1.60]}\end{array}$ \\
\hline Observations & 304 & 105 & 199 & 295 & 290 & 290 & 290 & 293 & 288 & 283 & 290 & 86 \\
\hline Within $R$-squared & 0.37 & 0.66 & 0.23 & 0.37 & 0.37 & 0.38 & 0.36 & 0.38 & 0.39 & 0.39 & 0.38 & 0.60 \\
\hline Number of countries & 24 & 7 & 17 & 23 & 23 & 23 & 23 & 23 & 24 & 24 & 24 & 24 \\
\hline
\end{tabular}

$t$-statistics in brackets

$* * p<0.01, * * p<0.05, * p<0.1$

Coefficients for country dummies not reported. 
Table 6. Global Variables

\begin{tabular}{|c|c|c|c|c|c|}
\hline & (1) & (2) & (3) & (4) & (5) \\
\hline Unemployment rate & $\begin{array}{l}0.28 * * * \\
{[2.84]}\end{array}$ & $\begin{array}{l}0.27 * * * \\
{[2.71]}\end{array}$ & $\begin{array}{l}0.21 * * \\
{[2.11]}\end{array}$ & $\begin{array}{l}0.34 * * * \\
{[3.32]}\end{array}$ & $\begin{array}{l}0.28^{* * * *} \\
{[2.70]}\end{array}$ \\
\hline Lead of disposable income growth & $\begin{array}{l}-0.25^{* * * *} \\
{[-3.35]}\end{array}$ & $\begin{array}{l}-0.24 * * * \\
{[-3.18]}\end{array}$ & $\begin{array}{l}-0.24 * * * \\
{[-3.35]}\end{array}$ & $\begin{array}{l}-0.22 * * * \\
{[-3.01]}\end{array}$ & $\begin{array}{l}-0.21 * * * \\
{[-2.90]}\end{array}$ \\
\hline Real short-term deposit rate & $\begin{array}{l}0.50^{* * *} \\
{[5.16]}\end{array}$ & $\begin{array}{l}0.51 * * * \\
{[5.24]}\end{array}$ & $\begin{array}{l}0.52^{* * *} \\
{[5.41]}\end{array}$ & $\begin{array}{l}0.46^{* * *} \\
{[4.64]}\end{array}$ & $\begin{array}{l}0.46^{* * *} \\
{[4.82]}\end{array}$ \\
\hline GDP volatility & $\begin{array}{l}0.65^{* * *} \\
{[2.95]}\end{array}$ & $\begin{array}{l}0.55^{* *} \\
{[2.29]}\end{array}$ & $\begin{array}{l}0.55^{* *} \\
{[2.49]}\end{array}$ & $\begin{array}{l}0.63 * * * \\
{[2.84]}\end{array}$ & $\begin{array}{l}0.49^{* *} \\
{[2.25]}\end{array}$ \\
\hline $\begin{array}{l}\text { Lagged financial worth (scaled by } \\
\text { disposable income) }\end{array}$ & $\begin{array}{l}-1.54 * * * \\
{[-2.94]}\end{array}$ & $\begin{array}{l}-1.52 * * * \\
{[-2.90]}\end{array}$ & $\begin{array}{l}-1.34 * * \\
{[-2.57]}\end{array}$ & $\begin{array}{l}-1.53 * * * \\
{[-2.94]}\end{array}$ & $\begin{array}{l}-1.28 * * \\
{[-2.50]}\end{array}$ \\
\hline Structural balance ( $\%$ of potential GDP) & $\begin{array}{l}-0.21 * * \\
{[-2.25]}\end{array}$ & $\begin{array}{l}-0.20^{* *} \\
{[-2.10]}\end{array}$ & $\begin{array}{l}-0.22^{* *} \\
{[-2.36]}\end{array}$ & $-0.19^{* *}$ & $\begin{array}{l}-0.19 * * \\
{[-2.09]}\end{array}$ \\
\hline World real GDP growth $(\%)$ & & $\begin{array}{l}-0.12 \\
{[-1.14]}\end{array}$ & & & \\
\hline Copper price/gold price & & & $\begin{array}{l}-7.69 * * * \\
{[-2.85]}\end{array}$ & & $\begin{array}{l}-9.33^{* * *} \\
{[-3.42]}\end{array}$ \\
\hline TED Spread $^{\mathrm{a}}$ & & & & $\begin{array}{l}0.76^{* *} \\
{[2.13]}\end{array}$ & $\begin{array}{l}1.02 * * * \\
{[2.85]}\end{array}$ \\
\hline Constant & $\begin{array}{l}5.06^{* * * *} \\
{[3.07]}\end{array}$ & $\begin{array}{l}5.80^{* * *} \\
{[3.28]}\end{array}$ & $\begin{array}{l}6.79 * * * \\
{[3.91]}\end{array}$ & $\begin{array}{l}4.29^{* *} \\
{[2.55]}\end{array}$ & $\begin{array}{l}6.11^{* * *} \\
{[3.53]}\end{array}$ \\
\hline Observations & 304 & 304 & 304 & 304 & 304 \\
\hline With & 0.37 & 0.37 & 0.39 & 0.38 & 0.41 \\
\hline Number of countries & 24 & 24 & 24 & 24 & 24 \\
\hline
\end{tabular}

$t$-statistics in brackets.

$* * * p<0.01, * * p<0.05, * p<0.1$.

Coefficients for country dummies not reported.

${ }^{\text {a}}$ The TED spread is the difference between the three-month interbank rate (the LIBOR) and the three-month U.S. T-bill rate.

intermediate input into industrial production. Its price therefore reflects future growth prospects. However, since commodity prices undergo wellknown cycles, we deflate the copper price by the gold price. The deflation by gold price serves an additional function. As Krugman (2011) has recently explained (referring to earlier analysis by Salant and Henderson, 1978), gold has more of an exhaustible nature than other commodities, which implies that it undergoes discrete shifts in response to changes in global prospects, particularly in response to the emergence of tail risks. As such, the copper-togold price ratio reflects global growth prospects discounted by downside risks. The TED spread is the difference between the three-month interbank rate (the LIBOR) and the three-month U.S. T-bill rate, and measures stress in the interbank market.

In Table 6 we check for the robustness of our baseline regression in column (2) of Table 4 when controlling for our three measures of global conditions. We are reassured that the coefficient estimates on our main 
Figure 7. Actual and Fitted Household Saving Rate (percent)

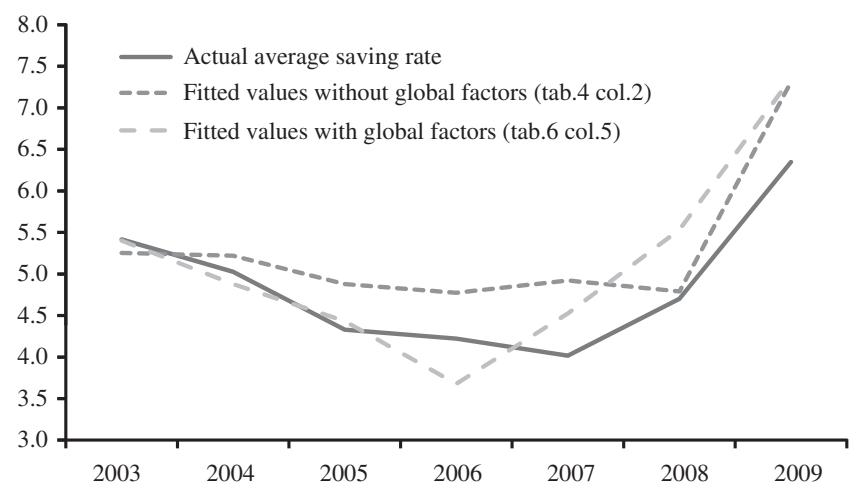

variables of interest are broadly unchanged in size and significance. The estimated coefficients for the global variables are also of interest. The contemporaneous world growth has the expected negative sign, but the coefficient is not significant at conventional levels. Our forward-looking measure of growth, the copper-to-gold price, is highly statistically significant. The expectation of stronger future growth reduces the need for saving. Finally, we find a significant and positive correlation between the TED spread and saving rates. ${ }^{14}$ Stress in the interbank market is generally associated with a tightening of credit supply which stimulates extra savings. In sum, these additional results suggest that household saving rates are affected by global conditions, but that domestic factors - in particular those related to uncertainty-remain salient.

\section{The Great Recession}

As shown in Figure 2, the crisis that started in mid-2007 and was followed by a deep recession in 2009 was characterized by a sharp slowdown in consumption growth (with an actual contraction in consumption in 2009 in many countries) and a sharp increase in the household saving rate. Our model traces the rise in saving rates fairly accurately: Figure 7 plots the time series of the saving rate averaged across countries together with the fitted values from our regressions in column (2) of Table 4 and from column (5) of Table 6, which includes the copper-to-gold price ratio and the TED spread. ${ }^{15}$ The fitted values from the regression trace the evolution of savings rates rather well. The specification that includes the global factors does somewhat

\footnotetext{
${ }^{14}$ An appreciation of the Swiss franc (relative to the U.S. dollar) is sometimes seen as a "flight to safety." Such appreciation behaves in a manner similar to a rise in the TED spread.

${ }^{15} \mathrm{We}$ only include those countries with sufficiently complete time-series data to generate fitted values for all the years between 2003 and 2009. This reduces the number of countries from 24 in column (2) of Table 4 and column (5) of Table 6 to 14.
} 
Figure 8. Change in Actual and Fitted Saving Rate, 2007-09 (percentage points)

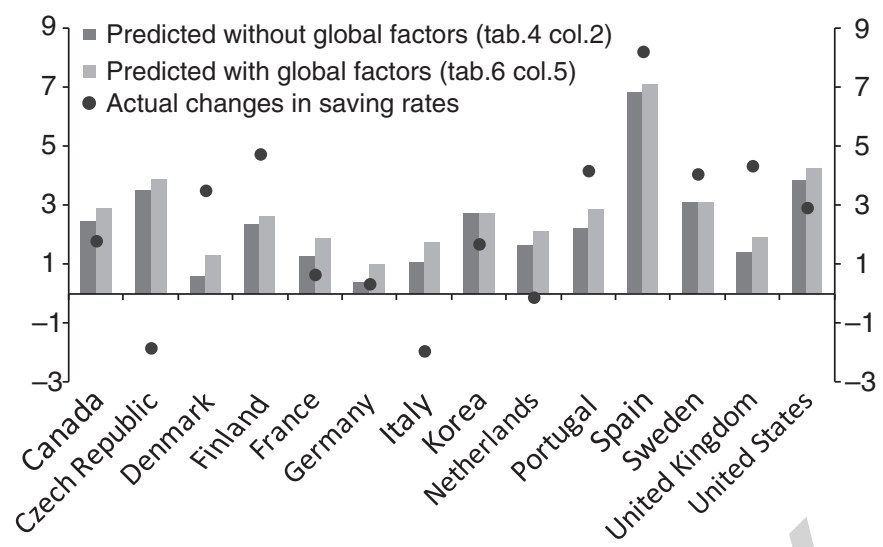

Figure 9. Contribution to Predicted Change in the Saving Rate between 2007 and 2009

(Total and by components, percentage points)

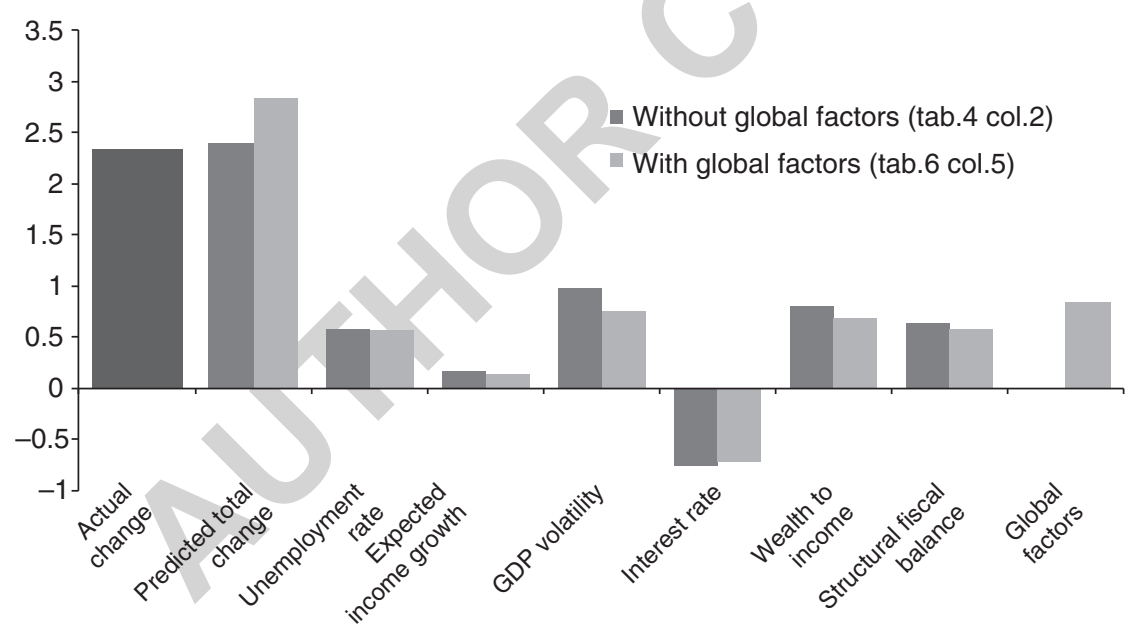

better in explaining the lower savings rates in the run up to the crisis - the period of "irrational exuberance"-as if saving rates were lower than warranted due to over-optimistic expectations of global growth. Figure 8 reveals that the model also does a surprisingly good job of predicting the rise in saving rates between 2007 and 2009 for individual countries, despite deficiencies such as missing data on housing wealth.

In Figure 9, we decompose the increase in the average fitted saving rate predicted by the model with and without global factors into the components attributed to each regressor. On average across countries, the model mildly 
over-predicts the actual increase in saving rates possibly because of the presence of habits in consumption that may slow down the actual speed of adjustment or because of the fact that consumers became aware only with a lag of the rapidly worsening economic conditions.

For the model without global factors, the increase in unemployment and in GDP volatility contributes more than 50 percent of the predicted increase in the saving rate. The inclusion of global variables modestly reduces the importance of the unemployment and GDP volatility, which still account for over two-fifths of the saving rate increase. In addition, a large reduction in asset values - with financial net worth as a share of disposable income falling in our data set from 1.7 to 1.2 -also was an important spur to increased saving. It is possible that the reduction in asset values resulted itself from the spike in uncertainty during the crisis; in any event, the need to rebuild wealth added to the motivation for increased precautionary savings. Thus, the direct effects of our unemployment and GDP volatility measures and the imperative to rebuild wealth highlight the central role of precautionary savings during the Great Recession.

The decline in expected income growth contributed only moderately to the rise in saving rates. Among policy variables, the fiscal stimulus during the crisis induced increased household saving rates but monetary easing, through falling real deposit rates, created an offsetting decline in the saving rate. Finally, household saving rates increased in response to the deteriorating outlook for global growth and tightening financial conditions.

Looking ahead, our econometric results imply that household saving rates are unlikely to return to the precrisis levels in the short run. Consumption habits may have limited the full adjustment to the new circumstances. Moreover, the continued uncertainty in the macroeconomic environment is likely to perpetuate compression in consumption. Sustaining the recovery will therefore require finding new sources of demand or strong and coordinated policy actions geared to restore confidence and reduce uncertainty.

\section{Conclusions}

Informed by the theoretical literature on precautionary savings, we have undertaken a cross-country analysis of the determinants of savings. While the importance of precautionary savings has been widely explored at the micro level, ours, we believe, is the first study to investigate the macroeconomic relevance of precautionary motives for household saving rates in a cross-country setting. ${ }^{16}$ For the advanced economies that are the focus of this paper, we find that aggregate savings do increase in the face of economy-wide uncertainty, in particular when affecting labor income rather than investment returns.

We apply our econometric estimates to investigate the reasons for the steep increase in saving rates during the Great Recession. The results show

\footnotetext{
${ }^{16}$ Previous studies have tried to control for precautionary motives only using very imperfect measures, such as inflation.
} 
Figure 10. News Reference Volume in Google Searches

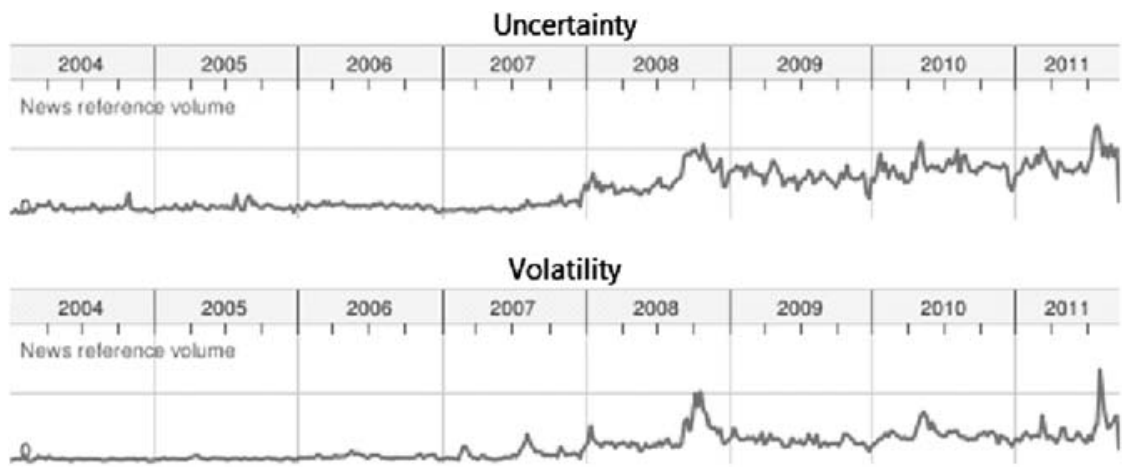

Source: Images and results courtesy of Google trends.

that more than two-fifths of the increase in savings can be directly related to the increase in unemployment risk and GDP volatility. Saving rates considerably increased also in response to financial wealth losses, which may have themselves been caused by the increase in uncertainty.

As we noted in the introduction, although a recovery ensued in 2010, an episodic sense of crisis has continued, and uncertainty has remained high. This new normal is reflected in the increased reference to the words "volatility" and "uncertainty" in press coverage of current events (Figure 10). It appears that uncertainty is here to stay-at least for a while. The implication is that saving rates will remain stable, or even rise during spikes in uncertainty. This complicates the process of economic recovery. Higher uncertainty and lower growth can become a "bad" equilibrium. The challenge for policymakers is that as they go about their task of renewing global growth, they must also pay particular attention to the consistency of their statements, especially to establish the credibility of their actions. As of this writing, the signs in this regard are not propitious. 


\section{APPENDIX}

Table A1. Data Appendix

\begin{tabular}{lc}
\hline Country & Time Period \\
\hline G7 Countries & \\
Canada & $1980-2010$ \\
France & $1980-2009$ \\
Germany & $1995-2009$ \\
Italy & $1990-2010$ \\
Japan & $1996-2008$ \\
U.K. & $1995-2009$ \\
U.S. & $1980-2010$ \\
& \\
Non-G7 Countries & \\
Australia & $1980-2008$ \\
Austria & $1995-2009$ \\
Belgium & $1995-2009$ \\
Czech Republic & $1995-2009$ \\
Denmark & $1995-2009$ \\
Estonia & $1995-2009$ \\
Finland & $1995-2010$ \\
Greece & $2000-2009$ \\
Ireland & $2002-2009$ \\
Luxembourg & $2006-2009$ \\
Korea & $1980-2010$ \\
Netherlands & $1990-2009$ \\
New Zealand & $1986-2006$ \\
Norway & $1992-2009$ \\
Portugal & $1995-2010$ \\
Slovakia & $1995-2008$ \\
Slovenia & $1995-2009$ \\
Spain & $2000-2009$ \\
Sweden & $1995-2010$ \\
Switzerland & $1995-2008$ \\
\hline &
\end{tabular}


Household net saving rate,

percent of disposable income

Unemployment rate

Real household net disposable income growth

Real short-term deposit rate

GDP volatility

Stock market volatility

Household financial net worth

Housing prices

General government structural balance in percent of potential GDP

Share of young (0-14 years) and old (65 + years),

in percent of total working-age population.

Domestic credit to private sector ( $\%$ of GDP)

World real GDP growth (\%)

Copper-to-gold price

TED spread
OECD's National Accounts.

IMF's World Economic Outlook.

OECD's National Accounts.

IMF's World Economic Outlook.

Instantaneous time-varying standard deviation of quarterly data on year-over-year growth of real GDP per capita based on a GARCH $(1,1)$ estimation. Real GDP per capita calculated using

data from the IMF's World Economic Outlook on real GDP and population, extended by data from Haver Analytics.

Standard deviation of daily changes in Morgan Stanley stock market index over the period of one year. Global Insight database.

OECD's Financial Annual Accounts.

Average annual house price index of all types of houses and vintages across the whole economy with following exceptions. For Belgium, France, Netherlands, Germany, and Finland, for all types of existing houses across the whole economy. For Austria, for all types of houses and vintages in the capital city. For Australia, for all types of existing houses in big cities. For Denmark and

Switzerland, for single-family houses of all vintages across the whole economy. Similarly for the United States and Canada, but only for existing vintages in the United States and new vintages in

Canada. Indices were rescaled to $2005=100$.

IMF's World Economic Outlook.

World Bank's World Development Indicators.

World Bank's World Development Indicators.

IMF's World Economic Outlook.

IMF's World Economic Outlook.

Haver Analytics. 


\section{REFERENCES}

Angeletos, George-Marios, 2007, "Uninsured Idiosyncratic Investment Risk and Aggregate Saving," Review of Economic Dynamics, Vol. 1, No. 1, pp. 1-30.

Bloom, Nicholas, 2009, "The Impact of Uncertainty Shocks," Econometrica, Vol. 77, No. 3, pp. 623-85.

Max Floetotto, Nir Jaimovich, Itay Saporta-Eksten, and Stephen Terry, 2011, "Really Uncertain Business Cycles," mimeo, available via the internet: http:// www.stanford.edu/ nbloom/RUBC_DRAFT.pdf.

Caballero, Ricardo J., 1991, "Earnings Uncertainty and Aggregate Wealth Accumulation," American Economic Review, Vol. 81, pp. 859-71.

Cagetti, Marco, 2003, "Wealth Accumulation over the Life Cycle and Precautionary Savings," Journal of Business and Economic Statistics, Vol. 21, No. 3, pp. 339-53.

Carroll, Christopher D., 1992, "The Buffer-Stock Theory of Saving: Some Macroeconomic Evidence," Brookings Papers on Economic Activity, Vol. 2, pp. 62-156.

and Andrew Samwick, 1997, "Buffer Stock Saving and the Life-Cycle Permanent Income Hypothesis," The Quarterly Journal of Economics, Vol. 112, pp. 1-55.

and Jiri Slacalek, 2009, The American Consumer: Reforming, or Just Resting?, Available via the Internet: www.econ.jhu.edu/people/ccarroll/papers/Reforming OrResting.pdf.

Jiri Slacalek, and Martin Sommer, 2012, “Dissecting Saving Dynamics: Measuring Credit, Uncertainty, and Wealth Effects," mimeo, available via the internet: http://www.econ2.jhu.edu/people/ccarroll/papers/cssUSSaving.pdf.

Deaton, Angus, 1991, "Saving and Liquidity Constraints," Econometrica, Vol. 59, pp. 1221-48.

Edwards, Sebastian, 1996, "Why are Latin America's Saving Rates So Low? An International Comparative Analysis," Journal of Development Economics, Vol. 51, pp. 5-44.

Eichengreen, Barry, and Kevin O'Rourke, 2010, "What Do the New Data Tell Us?," VoxEU.org. Available via the Internet: www.voxeu.org/index.php?q=node/3421.

Engen, Eric M., and Jonathan Gruber, 2001, "Unemployment Insurance and Precautionary Saving," Journal of Monetary Economics, Vol. 47, pp. 545-79.

Giavazzi, Francesco, and Michael McMahon, 2012, "Policy Uncertainty and Household Savings," The Review of Economics and Statistics, forthcoming.

Gourinchas, Pierre-Olivier, and Jonathan A. Parker, (2002), "Consumption over the Life Cycle," Econometrica, Vol. 70, No. 1, pp. 47-89.

Leland, Hayne E., 1968, "Saving and Uncertainty: The Precautionary Demand for Saving," The Quarterly Journal of Economics, Vol. 82, No. 3, pp. 465-73.

Loayza, Norman, Klaus Schmidt-Hebbel, and Luis Servén, 2000, "What Drives Private Saving Across the World," The Review of Economics and Statistics, Vol. 82, No. 2, pp. 165-81.

Krugman, Paul, 2011, Are Other Commodities Like Gold?, Available via the Internet: www.krugman.blogs.nytimes.com/2011/09/07/are-other-commodities-like-gold-quickand-wonkish/.

Masson, Paul R., Tamim Bayoumi, and Hossein Samiei, 1998, "International Evidence on the Determinants of Private Saving," The World Bank Economic Review, Vol. 12, No. 3, pp. 483-501. 
Romer, Christina D., 1990, "The Great Crash and the Onset of the Great Depression," The Quarterly Journal of Economics, Vol. 105, No. 3, pp. 597-624.

Salant, Stephen W., and Dale W. Henderson, 1978, "Market Anticipations of Government Policies and the Price of Gold," The Journal of Political Economy, Vol. 86, No. 4, pp. 627-48.

Sandmo, Agnar, 1970, "The Effect of Uncertainty on Saving Decisions," The Review of Economic Studies, Vol. 37, No. 3, pp. 353-60.

Schmidt-Hebbel, Klaus, Steven B. Webb, and Giancarlo Corsetti, 1992, "Household Saving in Developing Countries: First Cross-Country Evidence," The World Bank Economic Review, Vol. 6, No. 3, pp. 529-47.

Skinner, Jonathan, 1988, "Risky Income, Life Cycle Consumption, and Precautionary Saving," Journal of Monetary Economics, Vol. 22, pp. 237-55.

Zeldes, Stephen P., 1989, "Optimal Consumption with Stochastic Income: Deviations from Certainty Equivalence," Quarterly Journal of Economics, Vol. 104, pp. 275-98. 